\title{
Identifying Students' Attitudes Regarding Augmented Reality Applications in Science Classes
}

\author{
https://doi.org/10.3991/ijet.v14i22.11750 \\ Damla Karagozlu $(\bowtie)$ \\ Near East University, Mersin 10, Turkey \\ damla.karagozlu@neu.edu.tr \\ Nikolay N. Kosarenko \\ Plekhanov Russian University of Economics, Moscow, Russia \\ Olga V. Efimova \\ Moscow City Pedagogical University, Moscow, Russia \\ Vadim V. Zubov \\ Financial University under the Government of the Russian Federation, \\ Moscow, Russia
}

\begin{abstract}
As one of the developing technologies and increased use in the field of education, Augmented Reality (AR) technology adds a digital (audio, video, graphic and GPS location) layer to authentic world images. The aim of this study is to determine students' attitudes regarding AR contents developed for science education. The study group consists of 77 th grade students studying in a private college during 2018-2019 academic year spring semester. The study adopted quantitative data collection method and implemented Attitude Scale for Augmented Reality Applications. The collected data were analyzed through paired samples statistics, mean and standard deviation. The data analysis showed that students were satisfied with AR applications, found it interesting and easy to use and would like to use it in the future.
\end{abstract}

Keywords-Augmented Reality, Attitude, Science Class.

\section{Introduction}

The head-spinning developments in information and communication technologies change the lifestyle of the individual and the society and became an important indicator of a country's progress and level of development. This great increase in the importance of information and technology influenced the field of education like all other fields. The use of technology in education helps learners access information more easily, fosters the development of cognitive skills and helps learners construct information [1]. In today's world, there is a need to use new technologies associated with real life by combining them with effective learning methods in the classrooms in order to take learners to the center and increase their interest and motivation. Such tech- 
nologies have attracting features and advantages needed to help students gain the desired skills by creating a fluent learning setting and attracting students' attention [2][3]. One of these technologies is Augmented Reality (AR) which is widely used in the field of education recently. AR is the enrichment of real settings through virtual objects or information (audio, video, graphic, simulation, etc.) created by computerbased technologies [4][5]. In other words, AR technology is the enhancement of realworld views and perception of reality by situating two- and three-dimensional digital content into real world setting [6][7].

$\mathrm{AR}$ technology fosters the existing reality and consists of these three main characteristics:

- Combination of real and virtual.

- Real time interaction

- Three-dimensional record [8].

The concepts of AR and virtual reality are often confused with each other. Actually, AR is an extension of virtual reality. The point where AR differentiates from virtual reality is the fact that AR constructs a virtual infrastructure on an actual object. This means that in AR applications, virtual applications are shaped by a real setting whereas, in virtual reality, all activities are virtual [9].

There are two existing types of AR applications:

- Marker-based

- Location-based [10]

In marker-based AR, cameras firstly identify objects or specially designed markers in the world and images are processed. Later, it projects the 2D or 3D information on these real time objects or markers [11].

As for location-based AR, location data from mobile gadgets such as wireless network or global positioning system (GPS) are used and combined with the information created by the computer [6].

For the past 60 years, AR applications are created to be used in various fields [12]. According to [8], medical imaging, care and maintenance, explanation, planning robotic ways, entertainment and military plane navigation are the six areas where AR applications are used. It is possible to add more areas to this list. For example, informatics, advertising, design and health are also using AR.

When AR technology is reviewed for educational purposes, it is seen that AR is amongst the developing technologies for educational settings. [13] highlighted that AR applications are used in education because they support the interaction between reality and virtual setting perfectly, are used as concrete interface simulations to explain objects, and enables smooth transfer between the reality and the virtual. AR allows room for flexibility in learning as it offers a learning setting which can be adapted to real life setting [14]. Also, AR applications are distinguished from traditional paper learning and computer-assisted learning with realistic images, effective and sincere interface and interactive content [15]. 
[5] reviewed relevant literature and listed some of the advantages of AR technology in education as follows:

- Makes learning interesting [4]

- Establishes permanent learning [16]

- Increases academic success [17] (Lee, 2012)

- Concretizes learning of complex or abstract concepts, facts and objects [18]

- Makes lessons more enjoyable by contributing to its fun [19]

- Increases student motivation and improves student attitude toward the lesson [20]

- Positively influences success and learning outcomes [21]

- Can be used to teach events, objects or phenomenon that is difficult to observe, is small or dangerous [22]

- Ensure active in-class participation [23]

- Contributes to learner autonomy [17]

AR technology is widely used in science along with other disciplines such as medicine, geometry, architecture, mathematics, visual arts, language teaching, etc. [24]. AR technology can be said to be suitable to science structure due to its advantages such as realistic structure, making experiments easier, concretizing topics, being research and investigation-based and other characteristics [25]. When it is especially considered that physics topics have abstract and complex content, AR is seen as promising potential tool for learning these topics [26]. [23] examined studies on the use AR for educational purposes through content analysis and found that majority of the AR studies are conducted in the field of science.

The studies on AR practices in science from the literature are reviewed. [27] developed a location-based augmented reality setting with a five-step guidance mechanism in order to help students share information by letting them question during learning activities. The study group consisted on fifty-seven $4^{\text {th }}$ grade science students who were divided into two groups: experimental group taught through augmented reality approach and control group taught through traditional in-class practices. Students' learning behaviors were recorded and comparatively examined in terms of learning patterns and group interaction. The findings showed that students using interrogative learning activities based on augmented-reality experienced more interaction during the learning process.

[21] developed an interrogation-based augmented reality simulation system for the topic of matter structure at secondary school chemistry lesson. The students were able to use a 3-dimensional model and markers to control, combine and interact with micro pieces. Their study concluded that augmented reality tools have major complementary role in learning, are more effective for low-performance students, students have a positive perception toward this software and students' learning attitudes are associated with the software assessments.

[28] investigated the impact of augmented reality usage in chemistry classes on students' learning outcomes. The study was conducted in pre-test post-test design without a control group. Following the implementation, it was found that augmented reality application contributed to the learning of complex concepts in chemistry; posi- 
tively influenced the communication among students and the use of augmented reality application fosters science learning.

In other study, [29] focused on testing the impact of using augmented reality instructional materials on students' success, conceptual errors and in-class participation as well as identifying students' perceptions of augmented reality instructional materials. The augmented reality instructional material called UzayAR, which was developed for the study, was implemented with the 118 students in $7^{\text {th }}$ grade Science and Technology lesson by using descriptive research design. The findings from the study pointed out that the students from the experimental group with augmented reality materials were more successful compared to the students from the control group, have less errors in concepts but had no difference in terms of classroom participation.

In his study, [30] studied that effects of augmented reality application developed to be used in science laboratories, on university first year students' laboratory skills and laboratory activities. The study adopted pre-test post-test control group experimental research design and 76 students took part in the research. It was found that augmented reality application did not have a positive effect on students' laboratory skills but they developed a positive attitude toward science laboratory activities with augmented reality materials.

[31] concentrated on the relation between the students' success, attitude toward the lesson and attitude toward augmented reality application regarding the augmented reality application used in science lessons. The sample for the quasi-experimental research design included $1007^{\text {th }}$ grade students. The data from the study showed that there is a difference in terms of success and attitude toward the lessons between experimental group student who used augmented reality and control group students.

The review of relevant literature revealed an increase in the number of studies on the use of AR technology for science teaching in recent years. However, no study was found on the investigation of attitude toward AR technology at secondary school level in North Cyprus. In this regard, it is needed to meet fill this gap in the literature. Hence, the aim of this study is to determine impact of AR content designed for $7^{\text {th }}$ grade science teaching on students' attitude toward AR technology.

\section{Methodology}

This study adopted single-group pre-test-post-test experimental design from quantitative research approaches. Experimental design researches are those that test the cause-effect relation between the variables. In experimental studies, researchers observe the impact of at least one independent variable on one or more dependent variables. There are many types of experimental design. One of these, which is also used in this study, is the single-group pretest-posttest experimental design where independent variable is implemented to one group and measurements are conducted before and after the experiment. The difference between the mean scores of pretest and posttest indicates the impact of the independent variable on the dependent variable [32]. 


\subsection{Participants}

The sample group of the research consists of seventy-seven $7^{\text {th }}$ grade students at a private middle school in North Cyprus. The research conducted in spring semester of 2018-2019 academic year. The average age of students is 12 , and $51 \%$ of the students are female and $49 \%$ are male.

\subsection{Data collection tool}

In order to determine the attitudes of students towards the usage of AR application, Attitude Scale for Augmented Reality Applications at Secondary Schools consisting of 15 items and three factors which was developed by [33] was used. The students answered the attitude scale at the beginning of the semester and at the end of the semester after using AR applications. The collected data were analyzed through paired samples statistics, mean and standard deviation techniques.

\subsection{AG contents development process and application}

For this study, content in the form of animations were developed ready to be installed in a ready-made mobile AR application. These contents were prepared in regard to the $7^{\text {th }}$ grade science subject curriculum of the school where the study would be implemented. The topics were selected based on the interviews with Science teachers and students who were taught $7^{\text {th }}$ grade science topics in the previous year.

In the next step, contents were developed based on continuous feedback. During this process, the feasibility of the contents was assessed based on the views of teachers and students. The developed contents were finalized following the feedback from five instructional technology experts, three science education experts and one linguistic expert. The final versions of the contents were integrated into HPReveal, one of the AR applications. Thus, contents were made accessible to any mobile device with HPReveal application. Within the scope of the study, a different sticker was prepared for each of the contents and was distributed to students to stick it to the relevant section in their course books. The students were able to watch the relevant content by showing the sticker from their books to their tablets' cameras through HPReveal application. The topics of science lessons were taught with the support of AR content for 6 weeks.

\section{Results}

The findings regarding the items and sub-dimensions of the Attitude Scale for Augmented Reality are presented in this section. 


\subsection{Comparison of students' attitudes before and after augmented reality application based on scale items}

The changes in students' attitudes regarding AR applications during AR applications are presented in the table below. Descriptive statistics such as mean and standard deviations of the scores of students from the Attitude Scale for Augmented Reality Applications before the education and after the education are presented in Table 1.

Table 1. Comparison of Students' Attitudes Before and After Augmented Reality Applications According to Items

\begin{tabular}{|l|c|c|c|c|}
\hline & Pre-test & \multicolumn{2}{|c|}{ Post-test } \\
\hline & $\overline{\boldsymbol{x}}$ & $\boldsymbol{S}$ & $\overline{\boldsymbol{x}}$ & $\boldsymbol{S}$ \\
\hline 1.I enjoy the lessons conducted with AR applications. & 3,52 & 1,35 & 4,09 & 1,22 \\
\hline $\begin{array}{l}\text { 2.It increases my curiosity for the subject to see AR applications shown on } \\
\text { books with 3D objects, videos and animations. }\end{array}$ & 3,58 & 1,40 & 4,09 & 1,13 \\
\hline 3.I study more for the subject thanks to AR applications. & 3,36 & 1,20 & 3,87 & 1,13 \\
\hline 4.The 3D objects in AR applications bring a sense of reality in the context. & 3,49 & 1,29 & 4,12 & 0,99 \\
\hline 5.I attend to classes using AR applications more willingly. & 3,61 & 1,29 & 4,21 & 1,04 \\
\hline 6.I can pay more attention to the classes when AR applications are used. & 3,60 & 1,19 & 4,00 & 1,06 \\
\hline 7.I enjoy studying at home with AR applications. & 3,53 & 1,26 & 3,82 & 1,33 \\
\hline 8.I'm not interested in AR applications. & 2,49 & 1,39 & 1,78 & 1,02 \\
\hline 9.AR applications make learning more difficult for me as they confuse me. & 2,26 & 1,27 & 1,69 & 0,98 \\
\hline 10.There is no need to use AR applications in classes. & 2,49 & 1,40 & 1,84 & 1,03 \\
\hline 11.It is a waste of time to use AR applications in classes. & 2,45 & 1,46 & 2,18 & 1,26 \\
\hline 12.I get bored when using AR applications. & 2,45 & 1,38 & 2,05 & 1,22 \\
\hline 13.It is difficult to use AR applications. & 2,73 & 1,26 & 2,38 & 1,36 \\
\hline 14.I would like AR applications to be used in other classes as well. & 3,36 & 1,38 & 4,48 & 0,84 \\
\hline 15.I would future course books to include AR applications. & 3,36 & 1,33 & 4,44 & 0,70 \\
\hline
\end{tabular}

Although the students responded as "I agree" to positive items and as "I disagree" to negative items from the Attitude Scale for Augmented Reality Applications before the implementation, it was observed that there was an increase in the positive items and decrease in the negative items.

When the mean scores of students' responses are reviewed, it is seen that following AR applications experience, students enjoyed the lessons more, their curiosity increased after viewing 3D objects, videos and animations on the course book, 3D objects gave a sense of reality, they attend to AR classes more willingly and they wish to see AR applications in other classes as well.

\subsection{Comparison of students' attitudes before and after augmented reality applications according to sub-dimensions}

Paired samples statistics analysis technique was used in order to determine the student attitudes for using AR applications. The analysis conducted for the three subdimensions as regards the attitudes of students towards AR applications are given in table 2 . 
Paper-Identifying Students' Attitudes Regarding Augmented Reality Applications in Science Classes

Table 2. Comparison of Students' Attitudes from Pre-test and Post-test Regarding Augmented Reality Applications according to Sub-dimensions

\begin{tabular}{|l|l|c|c|c|c|c|c|}
\hline \multicolumn{1}{|c|}{ Reflective thinking tendencies } & \multicolumn{1}{|c|}{ Group } & N & Mean & SD & df & t & p \\
\hline \multirow{2}{*}{ Usage satisfaction } & Pre-test & 77 & 3.5288 & 1.00564 & 76 & -4.020 & .000 \\
\cline { 2 - 8 } & Post-test & 77 & 4.0278 & .91298 & & & \\
\hline \multirow{2}{*}{ Usage anxiety } & Pre-test & 77 & 2.4805 & 1.12811 & 76 & 3.815 & .000 \\
\cline { 2 - 8 } & Post-test & 77 & 1.9870 & .87182 & & & \\
\hline \multirow{2}{*}{ Usage willingness } & Pre-test & 77 & 3.3636 & 1.19659 & 76 & -8.291 & .000 \\
\hline & Post-test & 77 & 4.4610 & .61647 & & & \\
\hline
\end{tabular}

*Significant at the .05 level of confidence

As can be seen in table 2, statistically significant difference was observed in "usage satisfaction", "usage anxiety" and "usage willingness" tendencies of students as regards AR application after using AR application at science classes. When the usage tendencies of students who participated in the study are examined, it was found out that there is a significant difference $(\mathrm{t}=-4.020, \mathrm{p}<0.05)$ in favor of post-test between pre-test $(\mathrm{M}=3.5288, \mathrm{sd}=1.00564)$ and post-test $(\mathrm{M}=4.0278, \mathrm{sd}=.91298)$ scores. Usage anxiety tendency of students show significant difference in favor of post-test scores $(\mathrm{t}=3.815, \mathrm{p}<0.05)$ between pre-test $(\mathrm{M}=2.4805, \mathrm{sd}=1.12811)$ and post-test $(\mathrm{M}=1.9870$, $\mathrm{sd}=.87182)$ tendencies. An examination of the usage willingness of students showed significant difference $(\mathrm{t}=-8.291, \mathrm{p}<0.05)$ in favor of post-test scores between pre-test $(\mathrm{M}=3.3636, \mathrm{sd}=1.19659)$ and post-test $(\mathrm{M}=4.4610, \mathrm{sd}=.61647)$ scores. In this context, it can be said that the students were satisfied with the AR application used in the study and that they wanted to use it in the future, too. In addition, it can be said that the anxiety levels before using the application decreased after the study was completed.

\section{Discussion and Conclusion}

The attitudes of students toward AR applications were examined under three dimensions. An increase in the satisfaction levels of students were observed regarding the use of augmented reality applications in science education process. In parallel to this finding, [34] investigated he motivation of students who were taught by AR in the experimental group and those who were taught in the control group through traditional methods. The results of the study showed that the motivation of students in the experimental group increased and the student interviews indicated they AR application is fun, interesting and created curiosity toward learning. The interviews also revealed that the most liked applications by students are those with AR technology. Again, similar to these findings, [11] conducted a study on the science lessons of $8^{\text {th }}$ grade students and found that majority of the students had positive attitudes toward AR applications in lessons. Students stated that AR applications catch their attention and increase their motivation for learning in science lessons.

Another finding from the study is that there was an increase in students' wishes to use AR applications. The relevant literature shows similar findings as well. In their study, [35] emphasized that AR technology has the feature to attract attention and this 
has a positive influence on students' desire to use AR applications. This result is in line with results of [36].

Additionally, it was found that students' level of anxiety regarding AR applications decreased by the end of the study. In this regard, students expressed that AR applications are interesting, do not lead to confusion and waste of time, and the use of AR applications is not boring or difficult. Equally, [20] found that use of AR applications was easy for secondary school students. [37] expressed that AR applications are intriguing.

According to the findings of this study, AR applications offer an effective learning setting for students, they are interesting and easy to use, bring a sense of authenticity to the learning setting and have positive impact on the motivation toward the lessons they are used for. By the same token, students were found to be satisfied with the AR application in science lessons and they wish to use AR applications in other classes in the future.

\section{$5 \quad$ References}

[1] Leutner, D. (2014). Motivation and emotion as mediators in multimedia learning. Learning and Instruction, 29, 174-175, https://doi.org/10.1016/j.learninstruc.2013.05.004

[2] Tobar-Munoz, H., Baldiris, S. and Fabregat, R. (2017). Augmented reality game-based learning: Enriching Students' Experience during Reading Comprehension Activities. Journal of Educational Computing Research, 55, 901-936.https://doi.org/10.1177/ $\underline{0735633116689789}$

[3] Yildı, E. (2017). Augmented reality research and applications in education. New Trends and Issues Proceedings on Humanities and Social Sciences, 2(11), 238-243. https://doi.org/10.18844/prosoc.v2i11.1927

[4] Dunleavy, M., Dede, C. and Mitchell, R. (2009). Affordances and limitations of immersive participatory augmented reality simulations for teaching and learning. Journal of Science Education and Technology, 18(1), 7-22, https://doi.org/10.1007/s10956-008-9119-1

[5] Fidan, M. (2018). ARTIRILMIŞ GERÇEKLIKLE DESTEKLENMIŞ PROBLEME DAYALI FEN ÖĞRETIMININ AKADEMIK BAŞARI, KALICILIK, TUTUM VE ÖZYETERLIK INANCINA ETKİİ. Ph.D. BOLU ABANT IZZZT BAYSAL ÜNIVERSITESİ.

[6] Cheng, K. H. and Tsai, C. C. (2013). Affordances of augmented reality in science learning: Suggestions for future research. Journal of Science Education and Technology, 22(4), 449462, https://doi.org/10.1007/s10956-012-9405-9

[7] Cepeda-Galvis, P. A. (2018). Educational and Cultural Environments Enriched Using Augmented Reality Technology. New Trends and Issues Proceedings on Humanities and Social Sciences, 4(8), 52-59. https://doi.org/10.18844/prosoc.v4i8.2976

[8] Azuma, R. T. (1997). A survey of augmented reality. Teleoperators and Virtual Environments, 6(4), 355-385. https://doi.org/10.1162/pres.1997.6.4.355

[9] Tsai, C.-H. and Yen, J.-C. (2014). The augmented reality application of multimedia technology in aquatic organisms' instruction. Journal of Software Engineering and Applications, 7, 745-755, https://doi.org/10.4236/jsea.2014.79069.

[10] Dunleavy, M. (2014). Design principles for augmented reality learning. Tech Trends, 58(1), 28-34. https://doi.org/10.1007/s11528-013-0717-2 
[11] Cai, S., Chiang, F. K. and Wang, X. (2013). Using the augmented reality 3D technique for a convex imaging experiment in a physics course. International Journal of Engineering Education, 29(4), 858-865.

[12] Cai, H. (2013). Using augmented reality games as motivators for youth environmental education: An American Hart's tongue fern conservation project. Unpublished doctoral dissertation, State University of New York, New York.

[13] Billing Hurst, M. and Kato, H. (2002). Collaborative augmented reality. Communications of the ACM, 45(7), 64-70. https://doi.org/10.1145/514236.514265

[14] Barsom, E., Graaf land, M. and Schijven, M. (2016). Systematic review on the effectiveness of augmented reality applications in medical training. Surgical Endoscopy, 30, 41744183. https://doi.org/10.1007/s00464-016-4800-6

[15] Wang, Y., Anne, A. and Ropp, T. (2016). Applying the technology acceptance model to understand aviation students' perceptions toward augmented reality maintenance training instruction. International Journal of Aviation, Aeronautics, and Aerospace, 3(4), 1-13. https://doi.org/10.15394/ijaaa.2016.1144

[16] Wojciechowski, R. and Cellary, W. (2013). Evaluation of learners' attitude toward learning in ARIES augmented reality environments. Computers \& Education, 68, 570-585. https://doi.org/10.1016/j.compedu.2013.02.014

[17] Lee, K. (2012). Augmented reality in education and training. Tech Trends, 56(2), 13-21. https://doi.org/10.1007/s11528-012-0559-3

[18] Zagoranski, S. and Divjak, S. (2003). Use of augmented reality in education. IEEE, 2, 339342. https://doi.org/10.1109/EURCON.2003.1248213

[19] Rambli, D. R. A., Matcha, W. and Sulaiman, S. (2013). Fun learning with ar alphabet book for preschool children. Procedia Computer Science, 25, 211219.https://doi.org/10.1016/j.procs.2013.11.026

[20] Di Serio, Á., Ibáñez, M. B., \& Kloos, C. D. (2013). Impact of an augmented reality system on students' motivation for a visual art course. Computers \& Education,68, 586-596. https://doi.org/10.1016/j.compedu.2012.03.002

[21] Cai, S., Wang, X. and Chiang, F. K. (2014). A case study of augmented reality simulation system application in a chemistry course. Computers in Human Behavior, 37, 31- 40, https://doi.org/10.1016/j.chb.2014.04.018

[22] Abdüsselam, M. S. (2014). Artırılmış Gerçeklik Ortamı Kullanılarak Fizik Dersi Manyetizma Konusunda Öğretim Materyalinin Geliştirilmesi Ve Değerlendirilmesi. Yayımlanmamış Doktora Tezi, Karadeniz Teknik Üniversitesi Eğitim Bilimleri Enstitüsü, Trabzon.

[23] Bacca, J., Baldiris, S., Fabregat, R., Graf, S. ve Kinshuk. (2014). Augmented reality trends in education: A systematic review of research and applications. Educational Technology \& Society, 17(4), 133-149.

[24] Somyürek, S. (2014). Öğretim sürecinde Z kuşağının dikkatini çekme: Artırılmış gerçeklik. Eğitim Teknolojisi Kuram ve Uygulama, 4(1), 63-80.https://doi.org/10. 17943/etku. 88319

[25] Yoon, S., Anderson, E., Lin, J. and Elinich, K. (2017). How augmented reality enables conceptual understanding of challenging science content. Educational Technology \& Society, 20(1), 156-168.

[26] Dünser, A., Walker, L., Horner, H. and Bentall, D. (2012). Creating interactive physics education books with augmented reality. Proceedings of the 24th Australian ComputerHuman Interaction Conference, (pp. 107-114).https://doi.org/10.1145/ 2414536.2414554 
[27] Chiang, T. H., Yang, S. J., ve Hwang, G. J. (2014). An augmented reality-based mobile learning system to improve students' learning achievements and motivations in natural science inquiry activities. Journal of Educational Technology \& Society, 17(4), 352-365.

[28] Chiu, J. L., DeJaegher, C. J., \& Chao, J. (2015). The effects of augmented virtual science laboratories on middle school students' understanding of gas properties. Computers \& Education, 85, 59-73. https://doi.org/10.1016/j.compedu.2015.02.007

[29] Sırakaya, M. (2015). Artırılmış Gerçeklik Uygulamalarının Öğrencilerin Akademik Başarıları, Kavram Yanılgıları ve Derse Katılımlarına Etkisi (Doktora Tezi). Gazi Üniversitesi.

[30] Akçayır, M. (2016). Fen Laboratuvarında Artırılmış Gerçeklik Uygulamalarının Üniversite Öğrencilerinin Laboratuvar Becerilerine, Tutumlarına ve Görev Yüklerine Etkisi (Doktora Tezi). Gazi Üniversitesi.

[31] Şahin, D. (2017). Artırılmış Gerçeklik Teknolojisi ile Yapılan Fen Öğretiminin Ortaokul Öğrencilerinin Başarılarına ve Derse Karşı Tutumlarına Etkisi (Master Thesis). Atatürk Üniversitesi.

[32] Cohen, L. \& Manion, L. (1997). Reseacrh methods in education (4th ed.). Routledge: London and New York.

[33] Küçük, S., Yilmaz, R., Baydas, Ö., \& Göktas, Y. (2014). Augmented reality applications attitude scale in secondary schools: Validity and reliability study. Egitim ve Bilim, 39(176). https://doi.org/10.15390/EB.2014.3590

[34] Demirel, T. (2017). Argümantasyon yöntemi destekli artırılmış gerçeklik uygulamalarının akademik başarı, eleştirel düşünme becerisi, fen ve teknoloji dersine yönelik güdülenme ve argümantasyon becerisi üzerindeki etkisinin incelenmesi(Doctoral dissertation), Çukurova Üniversitesi.

[35] Yusoff, Z., \& Sunar, M. S. (2014). Augmented reality: a survey in educational environment. International Journal of Interactive Digital Media, 2(1) 1-8. Retrieved from http://magicx.my/ijidm/wp-content/uploads/2014-2-1-1- Zarwina.pdf

[36] Pastırmacioglu, B., Caliskan, S., Ozcan, D., \& Uzunboylu, H. (2018). Determining a Mobile Internet Acceptance Model of Special Education Teacher Candidates. International Journal of Interactive Mobile Technologies (Ijim), 12(4), 32.https://doi.org/10. 3991/ijim.v12i4.9198

[37] Zhang, J., Sung, Y. T., Hou, H. T., \& Chang, K. E. (2014). The development and evaluation of an augmented reality-based armillary sphere for astronomical observation instruction. Computers \& education, 73, 178-188. https://doi.org/10.1016/j.compedu.2014.01.003

\section{Authors}

Damla Karagozlu is working as an Assistant Professor in the Department of Computer Information Systems at Near East University, Lefkosa, T.R.N.C., Mersin 10 Turkey. E-mail id: damla.karagozlu@neu.edu.tr

Nikolay N. Kosarenko is $\mathrm{PhD}$ in Law and $\mathrm{PhD}$ in Philosophy, Associate Professor of the Department of State Legal and Criminal Law Disciplines at Plekhanov Russian University of Economics (36 Stremyannyi Pereulok, 115093, Moscow, Russia). He is a well-known Russian scientist and has a lot of published articles in Russian and International journals on the problems of law, philosophy and history of Russian law. $\mathrm{He}$ is also interested on the problems of philosophy of education, educational environment, scientific methodology. E-mail id: nkosarenko@yandex.ru 
Olga V. Efimova is $\mathrm{PhD}$ in Law, Associate Professor at the Department of Civil Law Disciplines at Moscow City Pedagogical University (4 Vtoroy Selskohoziajstvenny proezd, 107045, Moscow, Russia). She is a member of the certification commission of state universities' exams. Her research interests are connected with the problems of civil law, science education and publication activity. E-mail id:alisa03@mail.ru

Vadim V. Zubov is PhD in History, Associate Professor of the Department of Political Science and Mass Communications at Financial University under the Government of the Russian Federation (49 Leningrad sky prospects, 125993, Moscow, Russia). His research interests: Russian-German relations in the past era and the present stage, education, educational environment, students' self-development. E-mail id: zubov305@yandex.ru

Article submitted 2019-09-23. Resubmitted 2019-11-01. Final acceptance 2019-11-01. Final version published as submitted by the authors. 